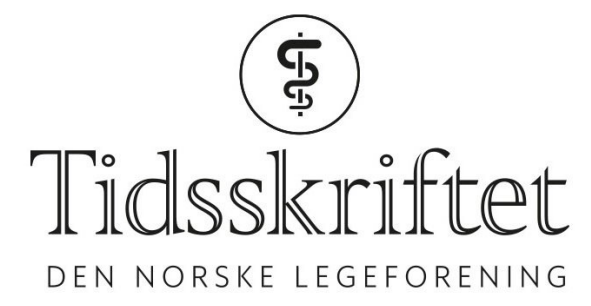

\title{
Nye retningslinjer for forebygging av hjerte- og karsykdom
}

RETTELSE

TOR OLE KLEMSDAL

BJØRN GJELSVIK

INGER ELLING

SIRIN JOHANSEN

SVERRE E. KJELDSEN

ØIVIND KRISTENSEN

STEINAR MADSEN

INGER NJØLSTAD

RANDI SELMER

SERENA TONSTAD

HILDE VOIE

Tidsskr Nor Legeforen 2017; 137: 1164-8

I Tidsskriftet nr. 16/2017 s. 1165 skal det i figuren stå Kvinne over de to kolonnene til venstre og Mann over de to kolonnene til høyre.

Dette er korrekt på nett. Vi beklager feilen.

Publisert: 16. oktober 2017. Tidsskr Nor Legeforen. DOI: 10.4045/tidsskr.17.0794

(C) Tidsskrift for Den norske legeforening 2020. Lastet ned fra tidsskriftet.no 